\title{
Evaluation of Kato-Katz and spontaneous sedimentation methods for the diagnosis of platynosomiasis in Neotropical primates
}

\author{
Avaliação dos métodos de sedimentação espontânea e Kato-Katz para o diagnóstico \\ da platinossomose em primatas neotropicais
}

Vitor Luís Tenório Mati ${ }^{1 *}$; Hudson Alves Pinto ${ }^{1}$; Alan Lane de Melo ${ }^{1}$

\begin{abstract}
${ }^{1}$ Departamento de Parasitologia, Instituto de Ciências Biológicas, Universidade Federal de Minas Gerais - UFMG, Belo Horizonte, MG, Brasil
\end{abstract}

Received October 10, 2014

Accepted November 5, 2014

\begin{abstract}
Platynosomiasis is a parasitic infection reported in non-human primates, including marmosets, and is frequently difficult to diagnose. In this study, the Kato-Katz method and the spontaneous sedimentation method were evaluated for their usefulness in identifying Platynosomum eggs in fecal samples from Callithrix penicillata that naturally harbor Platynosomum illiciens. Spontaneous sedimentation allowed the diagnosis of $41.7 \%(5 / 12)$ and $66.7 \%(8 / 12)$ of infected marmosets from one and three slides, respectively, prepared from the same fecal sample. The examination of a single Kato-Katz thick smear detected 83.3\% (10/12) of infection cases. The analysis of feces on three different days increased the rate of diagnosis, since $75 \%(9 / 12)$ and $100 \%(12 / 12)$ of the primates with platynosomiasis were identified using serial spontaneous sedimentation (3 slides/day) and the Kato-Katz method, respectively. The mean number of Platynosomum eggs per gram of feces determined via the Kato-Katz method was 71.7 (8-240). The spontaneous sedimentation method when performed in series is acceptable for the diagnosis of platynosomiasis. However, the Kato-Katz method, which was here used for the first time to detect this infection, has a higher diagnostic sensitivity and the advantage that a quantitative analysis of the eggs released in the host feces is possible.
\end{abstract}

Keywords: Fecal parasitological diagnosis, platynosomiasis, Platynosomum, marmosets, spontaneous sedimentation, Kato-Katz thick smear.

\section{Resumo}

A platinossomose é uma infecção parasitária relatada em primatas não-humanos, inclusive saguis, cujo diagnóstico é frequentemente difícil. Neste estudo, os métodos de sedimentação espontânea e Kato-Katz foram avaliados quanto à sua utilidade na identificaçáo de ovos de Platynosomum em amostras fecais de Callithrix penicillata naturalmente albergando Platynosomum illiciens. A sedimentação espontânea permitiu o diagnóstico de 41,7\% (5/12) e 66,7\% (8/12) dos saguis infectados a partir da análise de uma e três lâminas, respectivamente, preparadas de uma mesma amostra fecal. O exame de uma única lâmina de Kato-Katz detectou 83,3\% (10/12) dos casos de infecção. A análise de fezes em três dias diferentes aumentou as taxas de diagnóstico, uma vez que 75\% (9/12) e 100\% (12/12) dos primatas que apresentaram a platinossomose foram identificados, usando-se a sedimentação espontânea (três lâminas/dia) e o Kato-Katz em série, respectivamente. O número médio de ovos de Platynosomum por g de fezes, determinado através do método de Kato-Katz, foi de 71,7 (8-240). O método de sedimentação espontânea, quando realizado em série, é aceitável para o diagnóstico da platinossomose. Entretanto, o método de Kato-Katz, o qual foi pela primeira vez usado para se detectar essa infecção, mostrou uma maior sensibilidade diagnóstica, com a vantagem de que é possível uma análise quantitativa dos ovos liberados nas fezes do hospedeiro.

Palavras-chave: Diagnóstico parasitológico fecal, platinossomose, Platynosomum, saguis, sedimentação espontânea, Kato-Katz.

\footnotetext{
*Corresponding author: Vitor Luís Tenório Mati, Laboratório de Taxonomia e Biologia de Invertebrados, Departamento de Parasitologia, Instituto de Ciências Biológicas, Universidade Federal de Minas Gerais - UFMG, CP 486, CEP 30123-970, Belo Horizonte, MG, Brasil, e-mail: vitormati@yahoo.com.br
} 
Platynosomiasis, a parasitic disease caused by dicrocoeliid trematodes of the genus Platynosomum, often results in lesions in the biliary tract and gallbladder of birds and mammals harboring the adult parasite (RODRIGUES, 1963; KAZACOS et al., 1980; FOLEY, 1994; FERREIRA et al., 1999; ANDRADE et al., 2012; BASU \& CHARLES, 2014). In South America, the terrestrial mollusk Subulina octona and some isopods (Oniscidea species and Nagurus nanus) are the first and second intermediate hosts, respectively, of the fluke. Lizards are also involved in this life cycle as paratenic hosts (PINTO et al., 2014).

Species of Platynosomum have been reported in nonhuman primates, including apes (Pongo sp.), Old World (Macaca fascicularis) and New World monkeys (Callicebus moloch, Callimico goeldii, Callithrix spp., Cebuella pygmaea, Chiropotes satanas, and Saguinus spp.) (KINGSTON \& COSGROVE, 1967; COSGROVE et al., 1968; SHANTA, 1970; PORTER, 1972; TANTALEAN et al., 1990; WARREN et al., 1998; MELO, 2004; KAWHAGE et al., 2005; SOUSA et al., 2008; SILVA et al., 2012). Clinical manifestations have been absent or mild among New World monkeys infected with Platynosomum, although some deaths have also be attributed to the parasite (MELO, 2004; SOUSA et al., 2008; SILVA et al., 2012). The prognosis of the disease depends on the severity of chronic fibrosing hepatopathy, which is likely to be correlated with the parasite burden and the individual infected host response (SOUSA et al., 2008). Thus, a highly sensitive quantitative method of stool analysis is desirable for the diagnosis of platynosomiasis. Most new cases of the infection in nonhuman primates are diagnosed during necropsies, and coproparasitological diagnostic studies are rarely performed. As a result, primate specimens harboring Platynosomum spp. cannot usually be subjected to effective therapeutic intervention.

Considering that the veterinary management of primate platynosomiasis, including parasitological diagnosis, is still little known, the aim of the present study was to evaluate and compare the accuracy of two coproparasitological methods, the Kato-Katz method and spontaneous sedimentation, in identifying Platynosomum eggs in the feces of black-tufted marmosets (Callithrix penicillata), which are naturally infected with $P$. illiciens. In addition, previously published findings relating to other parasitological methods that have already been employed for the diagnosis of platynosomiasis in non-primate host are discussed.

Captive specimens of $C$. penicillata ( $\mathrm{n}=12 ; 7$ females and 5 males) that were naturally infected with Platynosomum illiciens
(= $P$. fastosum $)$ and maintained in the marmoset facility of the Instituto de Ciências Biológicas (ICB) of the Universidade Federal de Minas Gerais (UFMG) were studied. The definitive diagnosis of chronic infection with $P$. illiciens in each subject had been previously determined by a long series of routine parasitological tests using spontaneous sedimentation technique.

In this study, fresh samples of feces from all of these known positive marmosets were then collected three times in a week in order to evaluate the accuracy of the spontaneous sedimentation method (LUTZ, 1919) and the Kato-Katz method (KATZ et al., 1972).

One to three slides of fecal sediment obtained by spontaneous sedimentation were examined per day for each daily sample, but when the first slide examined was found to be positive for infection, no further analysis of the other slides was performed. This technique was chosen as the standard parasitological test because it is commonly used in Brazilian laboratories for the screening of helminth infections of wild animals.

Regarding the Kato-Katz thick smear, only one slide was prepared and examined per day. Once a positive result was obtained, no further testing was performed on subsequent days. In the quantitative analysis, the trematode eggs present in the Kato-Katz thick smears were counted and the number of eggs per gram of feces $\left(\mathrm{g}^{-1}\right)$ was estimated. Briefly, each fecal sample was placed on paper and sieved through a screen using a small metal spatula. Sieved feces were deposited into a well in a plastic template ( $41.7 \mathrm{mg}$ of feces) on a microscope slide and then covered with cellophane coated in glycerol and malachite green. This preparation was pressed against a hard surface to spread the sample evenly on top of the slide (a thick smear preparation). The number of Platynosomum eggs observed in each thick smear was multiplied by 24 to estimate the number of eggs per gram of feces (KATZ et al., 1972). All slides were evaluated under a light microscope $(100 \times$ total magnification) by the same author.

The sensitivity of each method was calculated and the McNemar test was used to compare data obtained, where differences were considered significant if $\mathrm{p}<0.05$. The use of marmosets was authorized by the Brazilian Institute of the Environment (Instituto Brasileiro do Meio Ambiente e Recursos Naturais Renováveis, IBAMA), and the experimental procedures were conducted in accordance with the animal research ethics committee of UFMG.

Both parasitological methods enabled the observation of typical eggs of Platynosomum in feces of $C$. penicillata (Figure 1).
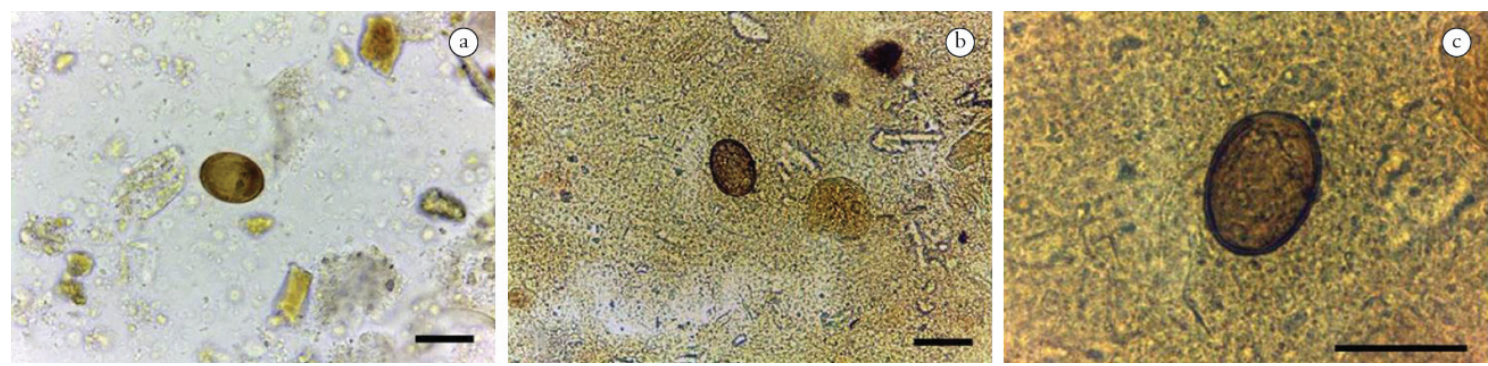

Figure 1. Eggs of Platynosomum illiciens observed during fecal analysis of specimens of naturally infected Callithrix penicillata, by using spontaneous sedimentation (a) and the Kato-Katz method (b). (c) Detail of a parasite egg in a Kato-Katz thick smear at a higher magnification. Scale bars $=40 \mu \mathrm{m}$. 
The specific identification of $P$. illiciens was confirmed during necropsies of two marmosets that subsequently died.

The individual results for each marmoset using both methods are shown in Table 1 . Spontaneous sedimentation allowed the identification of platynosomiasis in $66.7 \%$ (8/12) of infected primates by using three slides prepared from each fecal sample. Only 41.7\% (5/12) of platynosomiasis cases were identified when only one slide was evaluated. The examination of a single Kato-Katz thick smear detected 83.3\% (10/12) of infection cases. However, possibly due to the limited sample size, there was no statistically significant difference between the diagnosis rates of the two methods $(\mathrm{p}=0.449)$.

The serial analysis of feces over three days numerically increased the diagnostic sensitivities. In fact, 50\% (6/12) and 75\% (9/12) of primates with platynosomiasis were identified by the spontaneous sedimentation method when one and three slides were evaluated per day, respectively. Furthermore, serial evaluation of a single Kato-Katz thick smear per day identified $100 \%(12 / 12)$ of the C. penicillata infected with P. illiciens, with a mean of 71.7 (8-240) Platynosomum eggs per gram of feces. This is a clinically relevant pathological finding, although the rate of diagnosis of this method only differed significantly from the spontaneous sedimentation method when that analysis used only one slide per day $(\mathrm{p}=0.041)$.

The great importance of platynosomiasis in veterinary practice contrasts with the scarcity of studies on the standardization of parasitological methods for its diagnosis. These methods, in addition to identifying Platynosomum eggs, allow the parasite burden to be estimated and, thus, may inform the decisions taken by veterinarians. This is the first study of the accuracy of fecal methods of platynosomiasis diagnosis in primates. However, different qualitative methods have already been used for the identification of platynosomiasis in domestic cats (PALUMBO et al., 1974, 1976; CHUNG et al., 1977; TAYLOR \& PERRI, 1977; RAGOZO et al., 2002; SOUZA-DANTAS et al., 2007; KRECEK et al., 2010;
LEAL et al., 2011; ROCHA et al., 2014), although the sensitivity of these methods have not usually been analyzed.

According to Palumbo et al. (1976), the identification of feline platynosomiasis by coproscopy may be difficult due, at least in part, to the dicrocoeliid eggs being relatively small, very few of these stages being individually released per day by each parasite, and the variable morphology of both immature and mature eggs found in host feces. The number of eggs of $P$. illiciens released in feces has been found to correlate with the total number of trematodes in the host and the daily egg production by each fluke (FOLEY, 1994). Furthermore, the prepatent period for P. illiciens is relatively long and may lead to negative results. In cats, immature eggs were observed after 8 weeks of infection and mature eggs were only seen after 10-12 weeks of infection (TAYLOR \& PERRI, 1977).

In the present study, the Kato-Katz and spontaneous sedimentation methods allowed the diagnosis of platynosomiasis in marmosets. The diagnostic sensitivities of both tests were possible to be calculated, since the infections of marmosets were previously known (certain diagnosis). It is noted that a "gold standard" test for the diagnosis of platynosomiasis is not well established in the literature. Considering, for example, methods of stool analysis already employed for the parasitological diagnosis of this infection in cats, there are contradictory values for sensibilities obtained by centrifugal sedimentation (RETNASABAPATHY \& PRATHAP, 1971; PALUMBO et al., 1974; LEAL et al., 2011; BASU \& CHARLES, 2014) and flotation (PALUMBO et al., 1974; LEAL et al., 2011; ROCHA et al., 2014) methods. The diagnostic sensitivity may indeed vary with the number and physiology of flukes in the host. Furthermore, no conclusive detailed comparison was possible between the obtained data and those from other studies using different coproparasitological tests since neither of the methods evaluated had previously been used to identify eggs of Platynosomum spp. The formalin-ether sedimentation technique (RITCHIE, 1948) has been considered

Table 1. Qualitative and quantitative parasitological fecal examination performed on three different days using the spontaneous sedimentation and the Kato-Katz method for twelve specimens of Callithrix penicillata naturally infected with Platynosomum illiciens. FEC = fecal egg count $\left(\mathrm{g}^{-1}\right)$.

\begin{tabular}{|c|c|c|c|c|c|c|c|c|c|c|}
\hline \multirow{4}{*}{ Subject } & \multicolumn{6}{|c|}{ Spontaneous sedimentation } & \multicolumn{4}{|c|}{ Kato-Katz } \\
\hline & \multirow{2}{*}{\multicolumn{3}{|c|}{$\begin{array}{c}\text { One slide per day } \\
\text { Days }\end{array}$}} & \multicolumn{3}{|c|}{ Three slides per day } & \multirow{2}{*}{\multicolumn{3}{|c|}{$\begin{array}{c}\text { One thick smear per day } \\
\text { Days }\end{array}$}} & \multirow[t]{2}{*}{ FEC } \\
\hline & & & & & Day & & & & & \\
\hline & 1 & 2 & 3 & 1 & 2 & 3 & 1 & 2 & 3 & \\
\hline $\mathrm{P} 1$ & - & - & - & + & & & + & & & 48 \\
\hline $\mathrm{P} 2$ & + & & & + & & & + & & & 120 \\
\hline P3 & - & - & - & + & & & + & & & 48 \\
\hline P4 & + & & & + & & & + & & & 96 \\
\hline P5 & + & & & + & & & + & & & 120 \\
\hline P6 & - & - & + & + & & & + & & & 72 \\
\hline P7 & - & - & - & - & - & + & + & & & 24 \\
\hline P8 & + & & & + & & & + & & & 240 \\
\hline P9 & - & - & - & - & - & - & - & + & & 12 \\
\hline P10 & - & - & - & - & - & - & - & - & + & 8 \\
\hline P11 & + & & & + & & & + & & & 48 \\
\hline P12 & - & - & - & - & - & - & + & & & 24 \\
\hline Mean \pm SD & & & & & & & & & & $71.7 \pm 65.7$ \\
\hline
\end{tabular}


a good parasitological method for the diagnosis of infection in domestic cats (FOLEY, 1994; BASU \& CHARLES, 2014). A sensitivity of up to $100 \%$ ( $9 / 9$ cats) has already been reported for this technique (PALUMBO et al., 1974), and it has been observed to have a greater capacity for detecting feline platynosomiasis in comparison to a direct smear, centrifugation in zinc sulfate, or modified detergent and sugar flotations (PALUMBO et al., 1976; KRECEK et al., 2010). Leal et al. (2011) achieved greater success in the identification of infected cats using serial formalin-ether sedimentation $(80 \% ; 8 / 10$ cats) compared to a serial saturated sucrose flotation (only 3 cats), and confirmed previous observations that indicated that sedimentation methods are better than flotation methods for finding Platynosomum eggs. In general, this kind of test is considered superior to flotation techniques for observation of trematode eggs because of their high density. Indeed, many trematode eggs do not float or only float in solutions with a high specific gravity (BALLWEBER et al., 2014). However, positive results were observed for $12.5 \%$ of the fecal samples (5/40) from cats when a method involving the centrifugal flotation of feces in a sugar solution was used, whereas all samples were negative when the centrifugal sedimentation technique was used (ROCHA et al., 2014). Moreover, the parasitological diagnosis of platynosomiasis using centrifugation-sedimentation method was already shown to have a low sensitivity, especially for infections with reduced number of trematodes, since eggs were only observed in the feces of $34.7 \%$ (77/222) of cats that presented flukes at necropsy (RETNASABAPATHY \& PRATHAP, 1971).

Different qualitative methods have already been evaluated for the diagnosis of platynosomiasis, but spontaneous sedimentation, to our knowledge, has been largely unnoticed, except for a report of it having a high sensitivity in cats (KRECEK et al., 2010). This relative lack of studies of spontaneous sedimentation may be because of the already widespread use of the formalin-ether technique in the diagnosis of feline platynosomiasis, at least considering the published cases. In the present study, the sensitivity of the spontaneous sedimentation technique was lower when only one slide was analyzed. However, the serial evaluation over three consecutive days increased the diagnostic sensitivity to a similar level to that observed for the Kato-Katz method. The easy preparation and low cost of the spontaneous sedimentation, besides the absence of contact with chemical products, may make it a good alternative tool for the diagnosis of platynosomiasis, especially when it is performed in series.

Successive analysis of slides to increase the sensitivity of the diagnostic method, including those prepared by formalin-ether sedimentation, has already been suggested (FOLEY, 1994; LEAL et al., 2011). This recommendation is more logical when one considers that, in cats, each specimen of Platynosomum produces between 10 and 100 eggs per day, which corresponds to only $2-10 \mathrm{~g}^{-1}$ in the feces of a host infected with few (1-5) parasites. This information reinforces the finding that the number of eggs released in the feces varies not only according to the number of parasites, but also due to the intrinsically variable rate of egg deposition (PALUMBO et al., 1976).

Less attention has been given to quantitative fecal analysis in comparison to qualitative analysis of platynosomiasis. Among the different techniques evaluated so far for the parasitological diagnosis of this infection, none is quantitative in the way that the Kato-Katz method is, although quantitative data have occasionally been presented (PALUMBO et al., 1976; TAYLOR \& PERRI, 1977; LEAL et al., 2011). The use of this method to quantify the number of eggs may be comparatively easier than by quantitative formalin-ether sedimentation, which was adapted by Palumbo et al. (1976). In the present study, the Kato-Katz technique has shown a mean concentration of eggs in feces of $71.6 \mathrm{~g}^{-1}$ among the marmosets infected with $P$. illiciens. This value resembles the quantitative data available for cats, but a comparison using this parameter alone may not be adequate due to biological differences between these definitive hosts. Perhaps with increased knowledge about the biology of the parasite in primate hosts it will be possible to estimate the parasite burden from the mean concentration of eggs in the feces obtained in serial fecal analyses.

In human parasitology, besides its demonstrated importance for the diagnosis of schistosomiasis (KATZ et al., 1972; WHO, 2013), the Kato-Katz method has also been used to diagnose fascioliasis (ESTEBAN et al., 1997; EL-MORSHEDY et al., 2002), clonorchiasis (CHOI et al., 2005), opisthorchiasis (SOUKHATHAMMAVONG et al., 2011; LOVIS et al., 2012) and dicrocoeliasis (ASHRAFI, 2010; TAY et al., 2011). However, the Kato-Katz method is still not widely used in the diagnosis of animal trematodiasis. Anh et al. (2008) used three sensible diagnostic tests, including the Kato-Katz method, for the identification of small trematode eggs $(<50 \mu \mathrm{m})$ in fecal samples of domestic animals. In addition to the Kato-Katz method, formalin-ether sedimentation and a more laborious method combining filtration, sedimentation, and centrifugation (the Danish Bilharziasis Laboratory [DBL] method) were evaluated. In their study, the sensitivity of the techniques of detection of small trematode eggs was the same in cats as in pigs, whereas the Kato-Katz method was slightly less sensitive in dogs. Anh et al. (2008) recognized that this last observation might be due to the amounts of feces evaluated being small and/or the lack of a washing procedure in the technique making the detection of eggs on the slide more difficult. Moreover, the influence of the different number of slides analyzed and the use of serial daily samples to increase the sensitivity of the diagnostic methods was not considered. Indeed, a limitation of the Kato-Katz technique is its low sensitivity for detecting eggs when they are present in small numbers in feces (theoretical analytic sensitivity of $1 \mathrm{egg} / 41.7 \mathrm{mg}=24 \mathrm{~g}^{-1}$ ) (VLAS \& GRYSEELS, 1992).

Considering the two parasitological methods evaluated in the present study, spontaneous sedimentation is easier to perform and cheaper than the Kato-Katz method, and when carried out in series is acceptable for the diagnosis of platynosomiasis in marmosets, and possibly in other hosts. The Kato-Katz method has a higher diagnostic sensitivity with the advantage that the number of eggs excreted in the feces of the infected host can be quantified. It is a practical method that may also be useful in veterinary practice for identification and monitoring $P$. illiciens infection and complementing existing diagnostic methods. Parasitological surveys in Neotropical primates should be encouraged in order to better understand the epidemiology of platynosomiasis in these hosts. 


\section{References}

Andrade RL, Dantas AF, Pimentel LA, Galiza GJ, Carvalho FK, Costa VM, et al. Platynosomum fastosum-induced cholangiocarcinomas in cats. Vet Parasitol 2012; 190(1-2): 277-280. http://dx.doi.org/10.1016/j. vetpar.2012.04.015. PMid:22963714

Anh NTL, Phuong NT, Ha GH, Thu LT, Johansen MV, Murrell DK, et al. Evaluation of techniques for detection of small trematode eggs in faeces of domestic animals. Vet Parasitol 2008; 156(3-4): 346-349. http://dx.doi. org/10.1016/j.vetpar.2008.05.021. PMid:18583060

Ashrafi K. Human dicrocoeliasis in northern Iran: two case reports from Gilan province. Ann Trop Med Parasitol 2010; 104(4): 351-353. http:// dx.doi.org/10.1179/136485910X12647085215813. PMid:20659397

Ballweber LR, Beugnet F, Marchiondo AA, Payne PA. American Association of Veterinary Parasitologists' review of veterinary fecal flotation methods and factors influencing their accuracy and use: is there really one best technique? Vet Parasitol 2014; 204(1-2): 73-80. http://dx.doi. org/10.1016/j.vetpar.2014.05.009. PMid:24893692

Basu AK, Charles RA. A review of the cat liver fluke Platynosomum fastosum Kossack, 1910 (Trematoda: Dicrocoeliidae). Vet Parasitol 2014; 200(1-2): 1-7. http://dx.doi.org/10.1016/j.vetpar.2013.12.016. PMid:24412358

Choi MH, Ge T, Yuan S, Hong ST. Correlation of egg counts of Clonorchis sinensis by three methods of fecal examination. Korean J Parasitol 2005; 43(3): 115-117. http://dx.doi.org/10.3347/kjp.2005.43.3.115. PMid:16192753

Chung NY, Miyara AY, Chung G. The prevalence of feline liver flukes in the city and county of Honolulu. J Am Anim Hosp Assoc 1977; 13(2): 258-262.

Cosgrove GE, Nelson B, Gengozian N. Helminth parasites of the tamarin, Saguinus fuscicollis. Lab Anim Care 1968; 18(6): 654-656. PMid:4235361.

El-Morshedy H, Shehab AY, Zaki A, Farag HF. Intra-specimen and dayto-day variations of Fasciola egg counts in human stools. East Mediterr Health J 2002; 8(4-5): 619-625. PMid:15603045.

Esteban JG, Flores A, Aguirre C, Strauss W, Angles R, Mas-Coma $\mathrm{S}$. Presence of very high prevalence and intensity of infection with Fasciola hepatica among Aymara children from the Northern Bolivian Altiplano. Acta Trop 1997; 66(1): 1-14. http://dx.doi.org/10.1016/ S0001-706X(97)00669-4. PMid:9177091

Ferreira AM, Almeida EC, Labarthe NV. Liver fluke infection (Platynosomum concinnum) in Brazilian cats: prevalence and pathology. Feline Pract 1999; 27(2): 19-22.

Foley RH. Platynosomum concinnum infection in cats. Compend Contin Educ Pract Vet 1994; 16(10): 1271-1277.

Katz N, Chaves A, Pellegrino J. A simple device for quantitative stool thick-smear technique in Schistosomiasis mansoni. Rev Inst Med Trop Sao Paulo 1972; 14(6): 397-400. PMid:4675644.

Kawhage P, Pereira WLA, Silva KSM, Carvalho RA. Helmintofauna de caráter zoonótico em primatas não humanos mantidos em cativeiro no Centro Nacional de Primatas (Ananindeua, Pará, Brasil). Rev Univ Rural 2005; 25(S1): 43-44.

Kazacos KR, Dhillon AS, Winterfield RW, Thacker HL. Fatal hepatic trematodiasis in cockatoos due to Platynosomum proxillicens. Avian Dis 1980; 24(3): 788-793. http://dx.doi.org/10.2307/1589818. PMid:7447844

Kingston N, Cosgrove GE. Two new species of Platynosomum (Trematoda: Dicrocoeliidae) from South American monkeys. Proc Helminthol Soc Wash 1967; 34(2): 147-151.
Krecek RC, Moura L, Lucas H, Kelly P. Parasites of stray cats (Felis domesticus L., 1758) on St. Kitts, West Indies. Vet Parasitol 2010; 172(1-2): 147149. http://dx.doi.org/10.1016/j.vetpar.2010.04.033. PMid:20537465

Leal PDS, Campos DP, Rodrigues MLA, Botelho GG, Labarthe NV. Avaliação da administração oral de ácido ursodesoxicólico (AUDC) no diagnóstico da infecção natural por Platynosomum illiciens em gatos. Rev Bras Med Vet 2011; 33(4): 229-233.

Lovis L, Mak TK, Phongluxa K, Aye Soukhathammavong P, Vonghachack Y, Keiser J, et al. Efficacy of praziquantel against Schistosoma mekongi and Opisthorchis viverrini: a randomized, single-blinded dose-comparison trial. PLoS Negl Trop Dis 2012; 6(7): e1726.

Lutz A. O Schistosomum mansoni e a schistosomose, segundo observações feitas no Brasil. Mem Inst Oswaldo Cruz 1919; 11(1): 121-155. http:// dx.doi.org/10.1590/S0074-02761919000100006.

Melo AL. Helminths parasites of Callithrix geoffroyi. Lab Prim Newsl 2004; 43(2): 7-9.

Palumbo NE, Perri SFO, Loo B, Taylor D, Reece V. Cat liver fluke, Platynosomum concinnum, in Hawaii. Am J Vet Res 1974; 35(11): 1455. PMid:4429247.

Palumbo NE, Taylor D, Perri SF. Evaluation of fecal technics for the diagnosis of cat liver fluke infection. Lab Anim Sci 1976; 26(3): 490493. PMid:940311.

Pinto HA, Mati VLT, Melo AL. New insights into the life cycle of Platynosomum (Trematoda: Dicrocoeliidae). Parasitol Res 2014; 113(7): 2701-2707. http://dx.doi.org/10.1007/s00436-014-3926-5. PMid:24802870

Porter JA Jr. Parasites of marmosets. Lab Anim Sci 1972; 22(4): 503506. PMid:4340289.

Ragozo AMA, Muradian V, Silva JCO, Caravieri R, Amajoner VR, Magnabosco C, et al. Ocorrência de parasitos gastrintestinais em fezes de gatos das cidades de São Paulo e Guarulhos. BrazJ Vet Res Anim Sci 2002; 39(5): 244-246. http://dx.doi.org/10.1590/S1413-95962002000500005.

Retnasabapathy A, Prathap K. The liver-fluke Platynosomum fastosum in domestic cats. Vet Rec 1971; 88(3): 62-65. http://dx.doi.org/10.1136/ vr.88.3.62. PMid:5100594

Ritchie LS. An ether sedimentation technique for routine stool examinations. Bull U S Army Med Dep 1948; 8(4): 326. PMid:18911509.

Rocha NO, Portela RW, Camargo SS, Souza WR, Carvalho GC, Bahiense TC. Comparison of two coproparasitological techniques for the detection of Platynosomum sp. infection in cats. Vet Parasitol 2014; $204(3-4)$ : 392395. http://dx.doi.org/10.1016/j.vetpar.2014.04.022. PMid:24877787

Rodrigues HO. Contribuição ao estudo do gênero Platynosomum Looss, 1907: (Trematoda, Dicrocoeliidae). Mem Inst Oswaldo Cruz 1963; 61(3): 507-515. PMid:14141131.

Shanta CS. A species of Platynosomum from a monkey. Malaysian Vet J 1970; 5(1): 17-18.

Silva KS, Silva RJ, Pereira WL. Occurrence of infection by Platynosomum illiciens (Braun, 1901) in captive neotropical primates. Primates 2012; 53(1): 79-82. http://dx.doi.org/10.1007/s10329-011-0281-3. PMid:22071558

Soukhathammavong P, Odermatt P, Sayasone S, Vonghachack Y, Vounatsou P, Hatz C, et al. Efficacy and safety of mefloquine, artesunate, mefloquine-artesunate, tribendimidine, and praziquantel in patients with Opisthorchis viverrini: a randomised, exploratory, open-label, phase 2 trial. Lancet Infect Dis 2011; 11(2): 110-118. http://dx.doi.org/10.1016/ S1473-3099(10)70250-4. PMid:21111681 
Sousa MB, Leão AC, Coutinho JF, de Oliveira Ramos AM. Histopathology findings in common marmosets (Callithrix jacchus Linnaeus, 1758) with chronic weight loss associated with bile tract obstruction by infestation with Platynosomum (Loos, 1907). Primates 2008; 49(4): 283-287. http:// dx.doi.org/10.1007/s10329-008-0105-2. PMid:18841441

Souza-Dantas LM, Bastos OPM, Brener B, Salomão M, Guerrero J, Labarthe NV. Técnica de centrífugo-flutuação com sulfato de zinco no diagnóstico de helmintos gastrintestinais de gatos domésticos. Ciênc Rural 2007; 37(3): 904-906. http://dx.doi.org/10.1590/S0103-84782007000300051.

Tantalean M, Gonzalo A, Montoya E. Notes on some helminth parasites from Peruvian monkeys. Lab Prim Newsl 1990; 29(2): 6-8.

Tay SCK, Gbedema SY, Gyampomah TK. Accuracy of diagnosis of intestinal helminth parasites in a reference diagnostic laboratory in the
Ashanti region of Ghana. Int J Parasitol Res 2011; 3(1): 12-16. http:// dx.doi.org/10.9735/0975-3702.3.1.12-16.

Taylor D, Perri SF. Experimental infection of cats with the liver fluke Platynosomum concinnum. Am J Vet Res 1977; 38(1): 51-54. PMid:402094.

Vlas SJ, Gryseels B. Underestimation of Schistosoma mansoni prevalences. Parasitol Today 1992; 8(8): 274-277. http://dx.doi.org/10.1016/01694758(92)90144-Q. PMid:15463638

Warren KS, Swan RA, Hobbs RP, Heriyanto, Kuhn EM, Heeney JL. Platynosomum fastosum in ex-captive orangutans from Indonesia. $J$ Wildl Dis 1998; 34(3): 644-646. http://dx.doi.org/10.7589/0090-355834.3.644. PMid:9706579

World Health Organization - WHO. Assessing the efficacy of anthelminthic drugs against schistosomiasis and soil-transmitted helminthiases. Geneva: WHO Press; 2013. 